activities, with special reference to the physiological and environmental factors which may influence their efficiency.

The second investigation - into the effects of control of malaria on the state of nutritionis taking place in Keneba village. The Human Nutrition Research Unit aims at eradicating the malaria mosquitoes from the village. After a year, during which the number of mosquitoes was reduced by spraying, several changes had been noted in the people, and fewer showed signs of malnutrition. The fall in weight associated with the 1950 hungry season at Geneiri was over Io per cent., but in Keneba in 1951 it was less than 4 per cent. In addition to measures to control mosquitoes, Africans are being tested for malaria, filariasis, and hookworm, and investigations are being conducted into the nutritional value of the grains eaten. New kinds and varieties are being grown, and the Gambians are invited to try them to see how they like them. The Unit has also introduced tractors and modern fertilizers, a step which has considerably increased the crop yields on the same total area of land farmed.

These investigations being undertaken in West Africa benefit not only the people of the Gambia but people in all tropical countries. They are paid for in part by the U.K. Medical Research Council, which supplies the scientific workers, and by Colonial Development and Welfare funds, which provide the equipment and maintenance. The field investigations carried out in the Gambia are backed by laboratory research in London at the U.K. Medical Research Council's Nutrition Unit and the Applied Nutrition Unit at the London School of Hygiene and Tropical Medicine.

\title{
African Research and Study Program, Boston University
}

The African Research and Study Program, which was formally inaugurated at Boston University in July I953 (see Africa, xxiii. 3, p. 252), is now moving into a period of expanding activities. Its Director, Professor William Brown, made an extensive tour in Europe and Africa during the first half of that year, for the purpose of surveying and assessing research on Africa in progress. He visited the leading research institutions concerned with social sciences in Europe and Africa and prepared a comprehensive report for the Board of Overseas Training of the Ford Foundation.

Dr. Brown's initial preoccupations in connexion with the Program of Research and Study have been the establishment of a library, and the planning of a series of bibliographical surveys, as a basis for the organization of more intensive research at a later date. In addition to these activities courses are being arranged, within the existing departmental framework of the Graduate School of the University, on such subjects as Geography of Africa, Problems of contemporary Africa, Politics of contemporary Africa, as well as a Seminar in Cultural Anthropology.

Dr. Adelaide Hill, Instructor in Sociology at Sargent College and at the College of Liberal Arts, has been appointed Administrative Assistant to Professor Brown; in May-July 1953 Dr. Hill visited West and Central Africa, speaking to students and to numerous women's groups, mainly on the role of women in the United States. Dr. W. G. Newman, who has been actively engaged in the work of the Program, visited research organizations in the United Kingdom in the course of an investigation of African research resources in Britain. Mr. Daniel McCall of Columbia University has been appointed to the staff of the Program and, as well as assisting the Director in the planning of research, will serve as Instructor in Anthropology.

Oversea visitors to the African Research and Study Program during I953 included Lord Hailey, Dr. J. J. Maquet of I.R.S.A.C., Astrida, Professor Gaston Leduc of the Sorbonne, Paris, Mr. Kenneth Robinson of Nuffield College, Oxford, Miss Peter Ady, 
St. Anne's College, Oxford, and Dr. Audrey Richards, Director of the East African Institute of Social and Economic Research.

\section{Chura na Nyoka (The Toad and the Snake)}

THE Bulletin of C.E.P.S.I. (Centre des Problèmes Sociaux Indigènes) has published as a supplement to its issue of November 1953 the text and musical score of a play devised by Joseph Kiwele, and performed in Elisabethville in June 1952. The play is based on a traditional Kongo story and the arrangement includes dances, songs, and dialogue-the songs, composed by Kiwele, include traditional African melodies.

Kiwele, who was born in the village of Mpala, Lake Tanganyika, showed evidence of musical ability from childhood and received some training in European liturgical music while still at school. He came to Elisabethville as assistant to Dom Anschaire Lamoral, the founder of the well-known African choir 'Chorale à la Croix de cuivre'; Kiwele conceived the idea of training the choir to sing African music and wrote several collections of songs based on traditional airs. At this time he composed the work which made him widely known-his Missa Katanga, which was first sung at the Mission St. Jean, then at the Cathedral in Elisabethville and more recently in Antwerp. Kiwele then turned his attention to the composition of musical plays incorporating traditional songs and dances, of which Chura na Nyoka is the best known, but he returned to liturgical music, and on Christmas Eve I 952 his Missa ya Jubile was sung at the Mission St. Jean. This mass, dedicated to the Vicar Apostolic of Katanga in honour of the fiftieth year of his priesthood, marked a new level of musical achievement. Profoundly Christian in spirit and deeply responsive to the dramatic motives of the Mass, it is African not European in quality; drums and xylophones are used to accompany and reinforce the melodic themes, and the distinctive rhythms of African music form the framework of the whole composition. Dom Thomas More Weitz, O.S.B., in his introduction to the text of Chura na Nyoka, writes of the Missa ya Jubile: ' Cette très belle Messe . . . est vraiment un nouveau chef-d'œuvre de musique authentiquement religieuse. . . . Joseph Kiwele a indéniablement enrichi la musique bantoue. En effet, il parvient à exposer un thème en le répétant dans des rythmes différents, parfois usant du renversement, créant de la sorte un grand mouvement grâce auquel ses compositions . . forment un tout substantiel. Avant Kiwele, cela n'existait pas; au contraire, le thème, sauf dans les pièces courtes, était rapidement épuisé. . . . Joseph Kiwele . . . réussit à prouver que la musique bantoue mérite d'occuper une place dans la musique chorale, tant religieuse que profane.'

\section{A l'Institut d'Etudes Centrafricaines}

LE Club des Chercheurs de l'Institut d'Études Centrafricaines a organisé à Brazzaville, au Club-House de l'Institut, sa première manifestation publique. C'est M. Pepper, musicologue de l'I.E.C. et Président du Club, qui assuma la responsabilité de cette initiative en faisant entendre une série des enregistrements musicaux qu'il s'attache depuis plusieurs années à recueillir et à étudier.

Le Professeur Trochain, Directeur de l'Institut d'Études Centrafricaines, présenta la personnalité de M. Pepper, et l'ensemble de ses travaux depuis l'étude des langages tambourinés qui lui fut suggérée par le Gouverneur Général Éboué, jusqu'à l'étude élargie des langages musicaux et à 'l'aperception' du système fondamental de l'harmonie africaine.:

Herbert Pepper est en train de livrer, à l'ethnologie africaine entendue de façon la plus large, un enseignement fondamental. Ses derniers travaux prennent figure de découvertes; jamais peut-être le symbolisme bantou compris non plus de façon limitative et notamment figurative, mais entendu comme un vaste système vital, jamais ce symbolisme n'aura été 